\title{
Congenital Transmesenteric Hernia Without Bowel Strangulation in a Young Adult
}

\author{
Genç Erişkinde Barsak Strangülasyonu Olmadan Görülen Konjenital \\ Transmezenterik Fitık
}

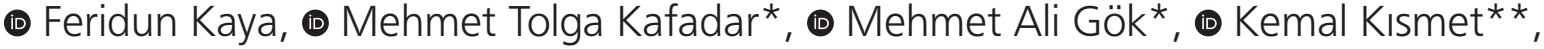 \\ ๑ Ertuğrul Ertaş***
}

University of Health Sciences, Mehmet Akif Inan Training and Research Hospital, Clinic of Gastroenterological Surgery, Şanlıurfa, Turkey

*University of Health Sciences, Mehmet Akif Inan Training and Research Hospital, Clinic of General Surgery, Şanlıurfa, Turkey

${ }^{* *}$ Ankara Training and Research Hospital, Clinic of General Surgery, Ankara, Turkey

***Düzce University Faculty of Medicine, Department of General Surgery, Düzce, Turkey

\begin{abstract}
Congenital internal hernia is a rare cause of bowel obstruction in adults and often presents with complications. A high index of suspicion, occasionally aided by appropriate radiological imaging, should lead to early surgical intervention and thus reduce morbidity and mortality. In this article, we describe a case of a 27-year-old man who presented with periumbilical and right lower quadrant pain. The patient who had undergone surgery for appendicitis was found to have an incidental mesenteric defect with herniating $30 \mathrm{~cm}$-long small bowel segment on exploration. The mesenteric defect was repaired and the herniated bowel segment was reduced to prevent volvulus. The patient made an uneventful recovery.
\end{abstract}

Keywords: Internal hernia, mesenteric defect, small bowel

\section{Introduction}

Transmesenteric hernia is a form of internal hernia through a congenital defect in the mesentery. The reported incidence of internal hernias ranges from 0.6 to $5.8 \%$ of all small bowel obstructions, and transmesenteric hernia accounts for approximately $5-10 \%$ of all internal hernias $(1,2)$. There is no hernia sac in this situation but only a mesenteric defect, which is present at birth. As with other hernias, they may lead to intestinal obstruction, strangulation and subsequently, bowel gangrene with
Konjenital internal fıtık, yetişkinlerde barsak tıkanıklığının nadir bir nedenidir ve sıklıkla komplikasyonlara neden olur. Bazen uygun radyolojik görüntülemeyle desteklenen yüksek bir şüphe, erken cerrahi müdahaleye sebep olup, morbidite ve mortaliteyi azaltabilmelidir. Bu yazıda, periumblikal ve sağ alt kadran ağrısı ile başvuran 27 yaşında bir erkek olgu sunuldu. Apandisit ön tanısıyla ameliyata alınan hastada, eksplorasyonda $30 \mathrm{~cm}$ 'lik ince barsak segmentinin herniye olduğu, insidental mezenterik bir defekt görüldü. Bu mezenterik defekt onarıldı ve volvulusu engellemek amacılla herniye olan barsak segmenti yerine konuldu. Hasta sorunsuz bir şekilde iyileşti.

Anahtar Sözcükler: İnternal fıtık, mezenterik defekt, ince barsak

varying length of gangrenous intestine. Internal hernias may develop at different abdominal locations. They are generally in the paraduodenal area (50\%), but may also be seen at transmesenteric, pericecal, intersigmoid and supravesical areas (1). Herniations to the foramen of Winslow, omentum, terminal mesoileum and broad ligament, or herniations to iatrogenic mesenteric defects are also possible. Although plain abdominal X-ray and computed tomography (CT) findings suggestive of an internal hernia have been described, the diagnosis of transmesenteric hernia is difficult, in part, because there
Address for Correspondence/Yazışma Adresi: Mehmet Tolga Kafadar University of Health Sciences, Mehmet Akif Inan Training and Research Hospital, Clinic of General Surgery, Şanlıurfa, Turkey

Phone: + 904143186000 E-mail: drtolgakafadar@hotmail.com ORCID ID: orcid.org/ 0000-0002-9178-7843 Received/Geliş Tarihi: 22 October 2017 Accepted/Kabul Tarihi: 22 March 2018
${ }^{1}$ Copyright 2018 by The Medical Bulletin of University of Health Sciences Haseki Training and Research Hospital
The Medical Bulletin of Haseki published by Galenos Yayinevi.

๑Telif Hakkı 2018 Sağlık Bilimleri Üniversitesi Haseki Eğitim ve Araştırma Hastanesi Haseki Tıp Bülteni, Galenos Yayınevi tarafindan basılmıștr. 
are no radiographic or laboratory findings to confirm the suspicion. Diagnosis is frequently made at surgery (3-7). Herein, we report the case of a 27-year-old man who presented with symptoms of acute appendicitis and diagnosed to have approximately $30 \mathrm{~cm}$-long small bowel segment herniated through a congenital transmesenteric hernia without bowel gangrene.

\section{Case}

An otherwise healthy 27-year-old man presented with a two-day history of severe periumbilical abdominal pain, multiple episodes of nausea without vomiting. The pain was acute in onset, severe, and continuous. The pain became prominent in the periumbilical area and localized in the right lower quadrant; it became worse over time. He had no other comorbid conditions and had not undergone any operations. On physical examination, he was lethargic with a pulse rate of $110 /$ minute, blood pressure of $110 / 70 \mathrm{mmHg}$, temperature of $37.5^{\circ} \mathrm{C}$ and respiratory rate of $25 /$ minute. Bowel sounds were audible. Results of laboratory investigations were normal except for a borderline elevated white blood cell count (WBC: $14000 / \mathrm{mm}^{3}$ ). On abdominal ultrasonography, a moderate amount of fluid was detected between the intestinal segments. Since the patient was thought to suffer acute appendicitis, it was deemed unnecessary to take an abdominal CT prior to surgery. After initial resuscitation, the abdomen was explored through a McBurney incision. Approximately 0.5 liters of reactional peritoneal fluid was drained. On exploration, the appendix was found to be inflamed and edematous. Appendectomy was performed. Since the terminal ileum was also edematous, we continued exploration from the ileocaecal valve to the proximal intestine. We found a $30 \mathrm{~cm}$-long herniated small bowel segment 90 to $120 \mathrm{~cm}$ distant from the ileocaecal valve. The segment was herniated through a large mesenteric defect (Figure). There was no bowel gangrene, and pulsations of mesenteric vessels were intact. The herniated bowel segment was reduced and the mesenteric defect was repaired with 2/0 silk sutures. Bowel function was resumed on the first postoperative day. Oral diet was initiated and tolerated well by the patient. He was discharged on the third postoperative day. On followup visit at 10 days, he was doing well. Histopathologic examination was interpreted as acute appendicitis despite the absence of a fecaloma in the appendix lumen on macroscopic examination. Patient's consent to publication was obtained.

\section{Discussion}

An internal hernia is formed by the protrusion of a viscus through a peritoneal or mesenteric aperture into a compartment of the abdominal cavity. It is estimated that internal hernias have an incidence of $0.2-0.9 \%$ and account for $0.6-5.8 \%$ of all cases of small bowel obstruction. Herniation can be congenital or acquired. Common sites of internal hernias are paraduodenal (50\%), supra- and/or peri-vesical, intersigmoid, foramen of Winslow, omentum, postoperative mesenteric defects, and congenital mesenteric defects $(8,9)$.

In 1836, Rokitansky reported the first case of mesenteric hernia, as an autopsy finding in which the cecum alone herniated through a hole near the ileocolic angle (10). The risk of developing a hernia in the presence of these defects is unknown (11). Mesenteric defects may be either congenital or acquired. Congenital defects are usually present in children and developmental defect is the likely cause, mainly in the mesentery of ileocaecal junction or ligament of Treitz. Various theories have been postulated to explain these developmental defects, including prenatal intestinal ischemia and subsequent thinning of the mesenteric leaves, intraperitoneal inflammation, trauma, partial development regression, and fenestration of the mesentery by the colon during the embryologic displacement into the umbilical cord. Transmesenteric hernia in adults is usually acquired resulting from previous abdominal surgery, particularly with Roux-en-Y anastomosis, as well as after abdominal trauma or intraperitoneal inflammation. These defects are found to be nearer to the ileocaecal junction or the ligament of Treitz (12).

Treves, in 1885, discovered a mesenteric region neighboring terminal ileum, which was wrapped by the junction formed by the ileocolic artery and the final branch of the ileal artery. This part was subsequently denoted as Treves' Field, which was free of fat, discernible vasculature, and lymph nodes, thus fairly prone to being damaged during development (13). Mesenteric defects have not been clearly explained from a pathogenetic aspect. One popular theory relates the cause to prenatal intestinal ischaemia and subsequent thinning of the mesenteric leaves because the prenatal intestinal ischaemia is associated with bowel atresia in 5.5\% of the paediatric population (1). Whereas many views, such as dorsal mesenteric regression, rapid increase of the length of a mesenteric segment, and mesentery being compressed by the colon during foetal midgut herniation into the yolk sac, have been advocated in its pathogenesis, these causes may be caused by foetal environment. In contrast, transmesenteric hernia has been associated with other anomalies such as cystic fibrosis and Hirschprung disease, which raise the suspicion of a genetic aetiology (12). Mesenteric defects cause bowel loops to enter and to exit through the defect, which is the main cause of 
obstructive symptoms of abdominal pain, distension, nausea, vomiting, and constipation. A herniated intestinal loop may distend, which may cause it to be incarcerated, strangulated, possibly culminating in shock. Patients with chronic defects may present with subtle and infrequent symptoms, making preoperative diagnosis fairly difficult. As such, bouts are thought to be due to peptic ulcer, biliary disease, or abdominal angina (2). Patients usually have a tender abdomen upon palpation. Eight percent of patients present with a palpable mass, while intestinal auscultation may yield no abnormality (14).

As there exist no radiological or biochemical signs or clues leading to diagnosis of mesenteric hernia, the latter is often difficult-to-diagnose. Although usually within normal range, leukocyte count may increase and metabolic acidosis may develop in the case of development of intestinal gangrene. The cases in the literature were generally admitted to hospital with symptoms of intestinal obstruction and strangulation and most of them needed a resection and anastomosis of bowel (15). However, in our case, the patient was admitted to the hospital with

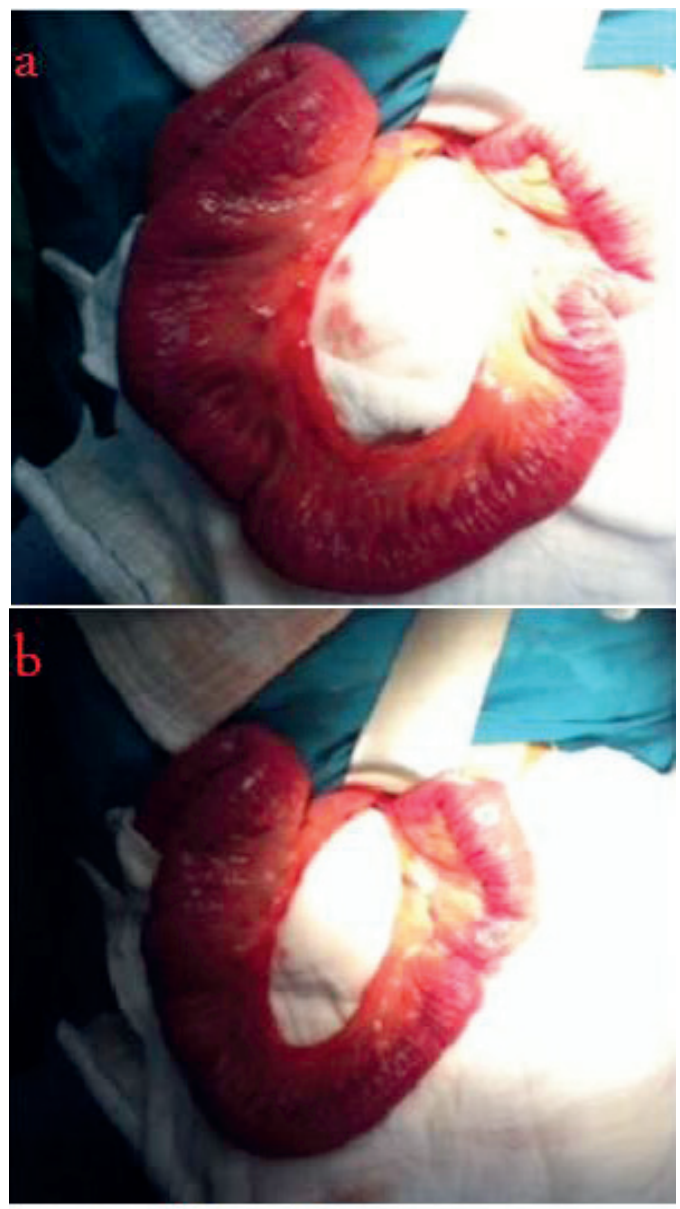

Figure. Intraoperative view of the mesenteric defect $(a, b)$ the symptoms of acute appendicitis. He had no symptoms of bowel obstruction, and at operation, no resection was needed.

Most of the reports of congenital mesenteric hernia involve pediatric population, and adult cases are rare. The preoperative diagnosis of this congenital hernia is very difficult. The diagnosis is generally made at surgery (16). In our case, the preoperative clinical picture and laboratory data suggested acute appendicitis, not intestinal obstruction, and the accurate diagnosis was made during operation.

In conclusion, internal hernia usually manifests as acute intestinal obstruction that require early diagnosis and immediate surgery, but sometimes the clinical process is not obvious as seen in our case. Due to lack of specific signs and symptoms, the diagnosis is confusing. Therefore, possibility of such rare cases should be kept in mind.

\section{Authorship Contributions}

Surgical and Medical Practices: F.K., M.T.K., K.K. Concept: F.K., M.T.K., M.A.G., E.E. Design: F.K., M.T.K., M.A.G., K.K. Data Collection or Processing: F.K., K.K., E.E. Analysis or Interpretation: F.K., M.T.K., M.A.G., E.E. Literature Search: M.T.K. Writing: F.K., M.T.K.

Conflict of Interest: No conflict of interest was declared by the authors.

Financial Disclosure: The authors declared that this study has received no financial support.

\section{References}

1. Newsom BD, Kukora JS. Congenital and acquired internal hernias: unusual causes of small bowel obstruction. Am J Surg 1986;152:279-85.

2. Vallumsetla R, Govind Rao N. Congenital transmesenteric internal hernia - A case report with literature review. Indian J Surg 2010;72:268-70.

3. Mangal AK, Massey A, Patel P. Congenital transmesenteric hernia presenting with intestinal obstruction in an adult: a case report. ANZ J Surg 2016;86:624-5.

4. Van der Mieren G, de Gheldere C, Vanclooster P. Transmesosigmoid hernia: report of a case and review of the literature. Acta Chir Belg 2005;105:653-5.

5. Guillem P, Cordonnier C, Bounoua F, Adams P, Duval G. Small bowel incarceration in a broad ligament defect. Surg Endosc 2003; 17:161-2.

6. Hashimoto D, Hirota M, Sakata K, Yagi Y, Baba H. Adult transmesenteric hernia: report of two cases. Surg Today 2012;42:489-92.

7. Alhayo S, Gosal P, Shakeshaft A. Incarcerated congenital transmesenteric hernia in an adult: a case report. J Surg Case Rep 2017;2017:rjx112.

8. Blachar A, Federle MP, Dodson SF. Internal hernia: clinical and imaging findings in 17 patients with emphasis on $\mathrm{CT}$ criteria. Radiology $2001 ; 218: 68-74$. 
9. Kulacoglu $H$, Tumer $H$, Aktimur $R$, Kusdemir A. Internal herniation with fatal outcome: herniation through an unusual apertura between epiploic appendices and greater omentum. Acta Chir Belg 2006;106:109-11.

10. Chaudhary P, Rao M, Kumar A, Khandelwal S, Gupta N, Arora MP. Spontaneous transmesenteric hernia: a rare cause of small bowel obstruction in an adult. Clin Pract 2013;3:e6.

11. Jain SK, Kaza RC, Garg PK. Incidental congenital transmesenteric hernia in an adult. Eur Rev Med Pharmacol Sci 2011;15:461-2.

12. Martin L, Merkle E, Thompson W. Review of internal hernias: Radiographic and clinical findings. AJR Am J Roentgenol 2006;186:703-17.
13. Veyrie $N$, Ata T, Fingerhut A. [Internal abdominal hernias]. J Chir (Paris) 2007;144:5S27-33.

14. Dowd MD, Barnett TM, Lelli J. Case 02-1993: A three-yearold boy with acute-onset abdominal pain. Pediatr Emerg Care 1993;9:174-8.

15. Butterworth J, Cross T, Butterworth W, Mousa P, Thomas S. Transmesenteric hernia: $A$ rare cause of bowel ischaemia in adults. Int J Surg Case Rep 2013;4:568-70.

16. Willems E, Willaert B, Van Slycke S. Transmesenteric hernia: a rare case of acute abdominal pain in children: a case report and review of the literature. Acta Chir Belg 2017:1-4. 